\title{
A biochemical viability assay is compatible with molecular methods for species identification
}

\author{
N.K. Richards ${ }^{1}$, L.M. Winder ${ }^{2}$, I.I. Iline ${ }^{1}$, M.A. Novoselov ${ }^{1}$, M.R. McNeill ${ }^{1}$ and \\ C.B. Phillips ${ }^{1}$ \\ ${ }^{1}$ AgResearch, Lincoln, Private Bag 4749, Canterbury 8140, New Zealand \\ ${ }^{2}$ Lincoln University, PO Box 84, Lincoln, New Zealand \\ Corresponding author: nicola.richards@agresearch.co.nz
}

\begin{abstract}
A biochemical viability assay was recently developed to quickly and easily assess the viability of small immobile arthropods, including eggs, intercepted on plant products. On finding a viable specimen, species identification often becomes the next hurdle. This paper demonstrates that amplifiable DNA is present in a used biochemical viability assay solution, and can be used for making taxonomic identifications. Cryptically labelled heattreated and untreated eggs of three weevil species (Listronotus bonariensis, Sitona lepidus and $S$. discoideus) were first tested for viability, then a $1135 \mathrm{bp}$ fragment of the cytochrome $c$ oxidase I gene was amplified from each viability assay solution in the presence of a fluorescent dye, SYBR Green. Melt curve analysis of the amplicons $(n=36)$ revealed three distinct melt profiles that correctly corresponded to each of the three weevil species. This shows that the biochemical viability assay is compatible with the application of subsequent molecular identification methods, which will facilitate the appropriate management response.
\end{abstract}

Keywords immobile arthropods, species identification, melt curve analysis.

\section{INTRODUCTION}

A biochemical viability assay was recently developed to help assess the viability of small immobile arthropods, such as juvenile scales and insect eggs (Phillips et al. 2013). This assay is particularly useful when evaluating the efficacy of treatments applied for pest management and international plant quarantine (Jamieson et al. 2009; Jamieson et al. 2012; Phillips et al. 2012).

Prior to development of the biochemical viability assay, methods for assessing the viability of immobile specimens involved either maintaining organisms in the laboratory to observe them for development, gauging their response to physical stimulation or assessing morphological characters such as turgidity and colour. These can be slow, technically difficult and/or subjective, and the validity of methods other than laboratory rearing has seldom been tested.

Existing gel isozyme electrophoresis methods were combined with a closely related ATP detection method, to create an assay where live specimens develop blue/purple coloured supernatants, while the supernatants from dead specimens remain unchanged (Phillips et al. 2013). Hence, viability is indicated by a simple colour change in the assay solution. No specialist equipment, expertise or facilities are needed for the assay, which has been validated 
to comply with an international standard (Phillips et al. 2013).

However, viability status is not the only question asked of organisms exposed to pest management and plant quarantine treatments. Often, it is also useful to identify the species involved. For juvenile insect stages, or for species having cryptic adult stages, the lack of defining morphological features makes identification based solely on morphology difficult. Hence sequence-based identification methods, such as DNA bar-coding (Hebert et al. 2003), have become an important tool in pest management and quarantine entomology for identifying insects in any life stage or condition (Floyd et al. 2010; Jinbo et al. 2011; Collins et al. 2012). In cases where the genus and potential species are known, and there is known sequence variation in an amplifiable gene, the identification process may be further stream-lined using DNA melt curve analysis (Chomič et al. 2011; Winder et al. 2011). Briefly, the process involves a fluorescent dye that becomes intercalated in the double stranded PCR product during amplification. On heating, the strands dissociate (or melt), releasing the dye and causing a significant drop in fluorescence. When the change in fluorescence is graphed against temperature, it generates a reproducible melt curve profile for that PCR product, which is dependent on its nucleotide sequence. Hence, melt curve profiles may be used to quickly differentiate between PCR products from different species where the nucleotide sequence is variable.

This paper describes how a biochemical viability assay solution containing an individual of an undiagnosed species can be used, first to measure specimen viability, and then DNA can be extracted from the assay solution to identify the species using any PCR-based diagnostic protocol. In this case, an existing DNA melt curve protocol that had been developed to identify the model species was used (Winder et al. 2011).

\section{MATERIALS AND METHODS} Insect specimens and preparation

Adult weevils of three species, Listronotus bonariensis (Kuschel), Sitona lepidus Gyllenhal and S. discoideus Gyllenhal, were collected from pasture in Canterbury, New Zealand, and maintained in the laboratory at $20^{\circ} \mathrm{C}$ and natural light to allow the weevils to produce eggs. All are introduced pests both in New Zealand and elsewhere (Marshall 1937; Phillips \& Barratt 2004; Phillips et al. 2008). Eggs (24-96 h old) from each species, were collected and placed on filter paper moistened with tap water in a $60 \mathrm{~mm}$ $\times 14 \mathrm{~mm}$ vented Petri dish, then divided into two subsamples, each containing 10-15 eggs. The first subsamples were placed in a Petri dish $(90 \times$ $10 \mathrm{~mm}$ ) on a circle of filter paper moistened with tap water, covered with the lid and then killed by heating for $1 \mathrm{~h}$ at $60^{\circ} \mathrm{C}$ in an EchoTherm ${ }^{\mathrm{TM}}$ IC20 Digital Electronic Chilling/Heating Dry Bath (Torrey Pines Scientific, Inc.). The second subsamples were left untreated as controls. One person was responsible for randomly placing 12 individual eggs (six treated, six controls) for each species into individual wells of a Terasaki microplate (72 wells $82,0 / 56 \mathrm{~mm}$, Greiner Bio-One). Each well was numbered and the order of egg placement was recorded, but not revealed to subsequent operators. As another test of egg viability, a sample of 29-30 eggs from each species was placed in a Petri dish $(90 \times$ $10 \mathrm{~mm}$ ) on filter paper moistened with tap water and incubated at $20^{\circ} \mathrm{C}$ in the dark, until larval emergence was completed.

\section{Biochemical viability assay}

Two additional people conducted biochemical viability assays on the eggs in the microplates. Assays were performed in batches of six. Under $12.5 \times$ magnification, each egg specimen was crushed in $7 \mu \mathrm{l}$ of biochemical viability assay stain (Phillips et al. 2013) using forceps that had been surface-sterilised with ethanol. The colour reaction of the assay was scored at $10 \mathrm{~min}$ after crushing. The assay supernatant was transferred into a labelled 0.2 $\mathrm{ml}$ tube and used for melt curve analysis.

\section{Melt curve analysis}

Melt curve analysis was conducted as described by Winder et al. (2011). Total DNA was extracted 
from each biochemical viability assay solution using a DNeasy Tissue Kit (Qiagen) in a final buffer volume of $50 \mu \mathrm{l}$. A $1135 \mathrm{bp}$ fragment of the mitochondrialgene, cytochrome coxidase subunit I (COI), was amplified using coleopteran universal primers previously designed for PCR: LCO-1490 (5'-GGTCAACAAATCATAAAGATATTGG-3') (Folmer et al. 1994) plus C1-N-2650-weevil (5'- CCNGTRAATARNGGGAATCATTG-3') (Vink \& Phillips 2007). The total PCR volume was $20 \mu \mathrm{l}$ and contained $4 \mu \mathrm{l}$ template DNA, $10 \mu \mathrm{l} 2 \times$ EXPRESS SYBR ${ }^{\circledR}$ GreenER $^{\mathrm{TM}}$ qPCR SuperMix (Invitrogen) and $0.2 \mu \mathrm{M}$ of each primer. Amplification was performed using the cycling profile: $95^{\circ} \mathrm{C}$ initial denaturation ( $2 \mathrm{~min}), 40$ cycles of $95^{\circ} \mathrm{C}$ denaturation $(15 \mathrm{~s})$, $45^{\circ} \mathrm{C}$ annealing $(1 \mathrm{~min})$ and $60^{\circ} \mathrm{C}$ extension (1 min). All samples were analysed in duplicate. Negative control tubes contained $4 \mu \mathrm{l}$ of distilled water instead of DNA.

Melt curve profiles were obtained using a thermal cycler (iQ5 real-time PCR detection system; Bio-Rad Laboratories Inc.). Immediately after PCR amplification, the following melt curve protocol was followed: $95^{\circ} \mathrm{C}$ denaturation $(1 \mathrm{~min}), 55^{\circ} \mathrm{C}$ annealing $(1 \mathrm{~min})$ and stepwise denaturation from 55 to $90^{\circ} \mathrm{C}$ with $0.2^{\circ} \mathrm{C}$ increments and $20 \mathrm{~s}$ hold. During this protocol, fluorescence data from melting curves were converted into melt profile charts using Bio-Rad optical system software, which plotted the negative derivative of fluorescence versus temperature $(-\mathrm{dF} / \mathrm{dT}$ versus $\mathrm{T})$. Melt peak temperatures $(\mathrm{Tm})$ were determined manually using tools provided in the software. Mean Tm values were calculated for replicate analyses of each specimen prior to species mean and standard deviation (SD) being determined. Each of the three weevil species produced a unique diagnostic melt curve profile (Winder et al. 2011).

\section{RESULTS}

\section{Biochemical viability assay}

After decoding the cryptic labels, all weevil eggs scored as dead $(n=18)$ by the biochemical viability assay had been exposed to heat treatment and all weevil eggs scored as live $(n=18)$ by the biochemical viability assay were from the untreated controls. For the eggs maintained to check viability, there was $100 \%$ emergence for all species.

\section{Melt curve analysis}

DNA was extracted and a 1135 bp fragment of the mitochondrial COI gene was amplified from all but one of the biochemical viability assay solutions $(n=36)$. The solution that failed to amplify had contained an untreated L. bonariensis egg. No amplification occurred in the negative controls. Each weevil species produced the distinct melt curve profile described by Winder et al. (2011). Amplicons from L. bonariensis produced a single peak with a Tm of $78.0 \pm 0.08^{\circ} \mathrm{C}($ mean $\pm \mathrm{SD}, \mathrm{n}=11)$. Amplicons from $S$. discoideus produced melt curve profiles with two distinct peaks $\left(\mathrm{Tm}=76.1 \pm 0.13^{\circ} \mathrm{C}\right.$ and $78.9 \pm 0.15^{\circ} \mathrm{C}, \mathrm{n}=12$ ). Sitona lepidus amplicons consistently produced melt profiles with four peaks ( $\mathrm{Tm}$ of the two dominant peaks $=76.4$ $\pm 0.13^{\circ} \mathrm{C}$ and $79.4 \pm 0.15^{\circ} \mathrm{C}, \mathrm{n}=12$ ). After decoding the cryptic labels, all samples were confirmed as correctly identified by melt curve analysis.

\section{DISCUSSION}

Biosecurity is important to New Zealand because increasing international trade and travel are recognised as major pathways for the introduction of non-indigenous species that can threaten productive sectors and natural ecosystems (Kriticos et al. 2005; Hulme 2009; Brockerhoff et al. 2010; McNeill et al. 2011). Integrated pest management and export biosecurity are also critical for maintaining NZ's export trade relationships (Jamieson et al. 2009, 2012).

The biochemical viability assay (Phillips et al. 2013) has bolstered the range of tools available for correctly assessing the viability of arthropods following application of new and existing treatments for pest management and plant quarantine (Jamieson et al. 2009, 2012; Phillips et al. 2012). It is a fast, technically easy and objective assay that has been validated to an international standard (Phillips et al. 2013).

The present study has demonstrated that a biochemical viability assay solution containing 
a crushed, unidentified specimen can be used for subsequent molecular analysis to provide additional taxonomic information about the specimen. Eggs of three weevil species were chosen for this study because they were concurrently being used to develop diagnostic protocols based on melt curve analysis (Winder et al. 2011). However, the principle that DNA present in viability assay solutions can be used to make taxonomic identifications is applicable to any organism. The biochemical viability assay also performs well across a very wide range of arthropods (Phillips et al. 2013). The three weevil species generated distinct melt curve profiles with single or multiple peaks because DNA strands of the same length will dissociate at different rates depending on the GA/AT ratio and sequence (Ririe et al. 1997). However, in cases where reference melt curve profiles have not been developed for the species of interest, standard diagnostic protocols, such as DNA sequencing, could still be used (e.g. Floyd et al. 2010; Collins et al. 2012).

One of the 36 biochemical assays did not provide amplifiable DNA in two separate PCR reactions, and hence the weevil involved could not be identified using the melt curve diagnostic protocol. Possibly this was due to an error during DNA extraction.

The presence of amplifiable DNA in biochemical viability assay solutions shows there is potential to develop a more powerful assay capable of assessing specimen viability and simultaneously identifying it, including cases where there is no clue as to the species or genus. Such refinements will assist quarantine authorities and pest managers to optimise their responses to pest detections.

\section{ACKNOWLEDGEMENTS}

Development of the biochemical viability assay was funded by AgResearch through the Better Border Biosecurity (B3) programme (www. b3nz.org) and by MPI through contract CO148. Optimisation and validation of the viability assay was supported by an AgResearch Pre-Seed fund to facilitate its use in commercial applications.

\section{REFERENCES}

Brockerhoff EG, Barratt BIP, Beggs JR, Fagan LL, Kay MK, Phillips CB, Vink CJ 2010. Impacts of exotic invertebrates on New Zealand's indigenous species and ecosystems. New Zealand Journal of Ecology 34: 158-174.

Chomič A, Winder L, Armstrong KF, Pearson MN, Hampton JG 2011. Detection and discrimination of members of the family Luteoviridae by real-time PCR and SYBR ${ }^{\circledR}$ GreenER $^{\mathrm{TM}}$ melting curve analysis. Journal of Virological Methods 171: 46-52.

Collins RA, Armstrong KF, Meier R, Yi Y, Brown SDJ, Cruickshank RH, Keeling S, Johnston C 2012. Barcoding and border biosecurity: identifying cyprinid fishes in the aquarium trade. PLoS ONE 7: e28381. doi:28310.21371/ journal.pone.0028381.

Floyd R, Lima J, deWaard J, Humble L, Hanner R 2010. Common goals: policy implications of DNA barcoding as a protocol for identification of arthropod pests. Biological Invasions 12: 2947-2954.

Folmer O, Black M, Hoeh W, Lutz R, Vrijenhoek R 1994. DNA primers for amplification of mitochondrial cytochrome coxidase subunit I from diverse metazoan invertebrates. Molecular Marine Biology and Biotechnology 3: 294-299.

Hebert PDN, Cywinska A, Ball SL, deWaard JR 2003. Biological identifications through DNA barcodes. Proceedings of the Royal Society Biological Sciences Series B 270: 313-321.

Hulme PE 2009. Trade, transport and trouble: managing invasive species pathways in an era of globalization. Journal of Applied Ecology 46: $10-18$.

Jamieson L, Chhagan A, Page-Weir N, Connolly P, DeSilva N, Phillips CB 2009. Coolstorage and controlled atmosphere coolstorage treatments to disinfest kiwifruit of live greedy scale (Hemiberlesia rapax) - Final Report. A report prepared for: ZESPRI Group Ltd Project EM0810 - Mitigating current and future market access threats (Part 3). Plant \& Food Research Ltd, Auckland, New Zealand. $25 \mathrm{p}$. 
Jamieson LE, Page-Weir NEM, Chhagan A, Brash DW, Klementz D, Bycroft BL, Connolly PG, Waddell BC, Gilbertson R, Bollen F, Woolf $A B$ 2012. Phosphine fumigation to disinfest kiwifruit. New Zealand Plant Protection 65: 35-43.

Jinbo U, Kato T, Ito M 2011. Current progress in DNA barcoding and future implications for entomology. Entomological Science 14: 107124.

Kriticos DJ, Phillips CB, Suckling DM 2005. Improving border biosecurity: potential economic benefits to New Zealand. New Zealand Plant Protection 58: 1-6.

Marshall GAK 1937. New Curculionidae collected from New Zealand. The Transactions and Proceedings of the Royal Society of New Zealand 67: 316-340.

McNeill M, Phillips C, Young S, Shah F, Alders L, Bell N, Gerard E, Littlejohn R 2011. Transportation of nonindigenous species via soil on international aircraft passengers' footwear. Biological Invasions 13: 2799-2815.

Phillips CB, Barratt BIP 2004. A guide to assist detection of newly arrived Sitona species (Coleoptera: Curculionidae) in New Zealand and Australia. Proceedings of 8th Australasian Conference on Grassland Invertebrate Ecology. Pp. 22-33.

Phillips CB, Baird DB, Iline II, McNeill MR, Proffitt JR, Goldson SL, Kean JM 2008. East meets West: Adaptive evolution of an insect introduced for biological control. Journal of Applied Ecology 45: 948-956.
Phillips CB, Iline I, Novoselov M, McNeill MR, Richards N, van Koten C 2012. Time between methyl bromide fumigation and mortality of Musca domestica Linnaeus (house fly) eggs. Ministry for Primary Industries operational research paper. http://www.mpi.govt.nz/ news-resources/publications.aspx, ISBN No: 978-0-478-38840-4. 60 p.

Phillips C, Iline I, Novoselov M, Richards N, McNeill M 2013. Development and validation of a quick, easily used biochemical assay for evaluating the viability of small immobile arthropods. Journal of Economic Entomology 106: in press.

Ririe KM, Rasmussen RP, Wittwer CT 1997. Product differentiation by analysis of DNA melting curves during the polymerase chain reaction. Analytical Biochemistry 245: 154160.

Vink CJ, Phillips CB 2007. First record of Sitona discoideus Gyllenhal 1834 (Coleoptera: Curculionidae) on Norfolk Island. New Zealand Journal of Zoology 34: 283-287.

Winder L, Phillips C, Richards N, Ochoa-Corona F, Hardwick S, Vink CJ, Goldson S 2011. Evaluation of DNA melting analysis as a tool for species identification. Methods in Ecology and Evolution 2: 312-320. 